\title{
Study of activity transcription factors C/EBP $\alpha$ in region - 53 to - 33 of promoter apolipoprotein B gene
}

\author{
Kátia Cristina Dantas ${ }^{1}$, Sérgio Paulo Bydlowski ${ }^{1,2}$, Estela Maria Novak ${ }^{1,2^{*}}$ \\ ${ }^{1}$ Research and Molecular Biology Division, Fundação Pró-Sangue Hemocentro de São Paulo, ${ }^{2}$ Department of \\ Hematology, University of São Paulo Medical School, Brazil
}

*Correspondence:

E. M. Novak

Research and Molecular

Biology Division

Fundação Pró-Sangue

Hemocentro de São Paulo

Av. Dr. Enéas de Carvalho Aguiar, 155-

$1^{\circ}$ Andar.

05403-000 - São Paulo, SP - Brazil

E-mail: enovak@usp.br
Apolipoprotein $B(A p o B)$ plays a major role in the regulation of cellular cholesterol homeostasis and pathogenesis of atherosclerosis. This protein acts as a ligand for the cellular recognition and catabolism of low density lipoprotein (LDL) by the LDL receptor. Previous studies have shown that the expression of apoB in hepatic cells is regulated by the interaction of factors binding to enhancer elements in intron 2 and three elements designated III, IV and $V$. These elements lie within regions respectively -86 to -62, -72 to -53 and -53 to -33 from the $A p o B$ promoter. In this study, we have suggested that transcription factor $C / E B P \alpha$, which binds to the -53 to -33 region of the apoB, interacts with the $H N F-4$ synergistic complex and $C / E B P \alpha$ factors within -86 to -53 and may contribute to increase transcription of the ApoB gene.

\section{INTRODUCTION}

Apolipoproteins are important constituents of lipoprotein particles and play a central role in the transport and metabolism of lipids (Goldstein et al., 1983). Different lipoproteins and apo have been identified. Recent epidemiological studies have shown the importance of the apolipoprotein B, and its direct correlation with the incidence of coronary heart disease (Sattar et al., 2004; Olofsson, Borén, 2005; Barter et al., 2006; Thompson, Danesh, 2006). Apolipoprotein B (apo $\mathrm{B}$ ) is a constituent of several lipoproteins and acts as a ligand for cell recognition and catabolism of low density lipoprotein (LDL) by the LDL receptor (Goldstein, Brown 1977; Brown, Goldstein, 1986). It is the structural protein moiety of plasma low density lipoprotein (LDL), comprising $23.8 \%$ of the LDL particle (Goldstein,
Brown, 1983). Thus, it is reasonable to expect that changes in the regulation of apolipoprotein B synthesis will affect the plasma lipids or lipoprotein profiles and contribute to the pathogenesis of coronary heart disease (Grundy, 2005; Barter et al., 2006). Apo B gene is localized in chromosome 2pter-2p24 and comprises 29 exons and 28 introns (Huang, Manson, 1986), and it is expressed in the liver, intestine and placenta, showing that ApoB gene transcription is regulated in a tissuespecific manner (Zannis et al., 2001). In humans, there are two forms of apolipoprotein B, namely apoB-100 and apoB-48. Apolipoprotein B-100 is expressed in the liver and is the main protein part of low density lipoprotein. In contrast, Apo B-48 is synthesized in the small intestine and is a constituent of chylomicrons and their remnants (Breslow, 1988; Lilja et al., 1999; Zannis et al., 2001). Hepatic apoB gene transcription is regulated by several 
regions, including the proximal 150 bases pairs of the promoter and enhancer elements in intron 2 (Brooks et al., 1992). Hepatic apoB gene transcription is regulated by regions localized in the -150 to +124 proximal promoter region of apoB (Kardassis et al., 1992). Specifically, the expression of ApoB in hepatic cells is controlled mainly by interaction of regulator proteins that bind to three elements designated III, IV and V, located respectively within the regions -86 to $-62,-72$ to -53 and -53 to -33 , respectively (Kardassis et al., 1992; Zannis et al., 2001). These regions interact specifically with proteins regulatory present in the liver as HNF-4 and C/EBP $\alpha$ (Kardassis et al., 1992; Metzger et al., 1993). HNF-4 (Hepatic nuclear factor-4) was classified as an orphan nuclear receptor and belongs to the superfamily of steroid-thyroid hormone receptors (Sladek et al., 1990), while C/EBP $\alpha$ (CAAT enhancerbinding protein alpha) is a positive acting transcription factor of the bZip family of proteins (Landschultz et al., 1988; Metzger et al., 1993). Both transcription factor have an overlapping binding site within the region -86 to -53 from the ApoB promoter, and act synergically to activate transcription (Kardassis et al., 1992). We have shown previously that mechanisms involving the interaction between $\mathrm{HNF}-4$ and $\mathrm{C} / \mathrm{EBP} \alpha$ factors in Apo $\mathrm{B}$ promoter require a perfect 5 '-CCTTTGGA-3' motif to facilitate the interaction between these two factors (Novak et al., 1998). As shown in figure 1, C/EBP $\alpha$ factor binds in two locations, element IV (-72 to -53$)$ and element V (-53 to -33). Element IV contains the core recognition sequence GCAAT of the transcription factor $\mathrm{C} / \mathrm{EBP} \pm$ and is localized within -72 to- 53 Apo $\mathrm{B}$ region. However, C/EBP $\alpha$ also recognizes the GCAAG sequence located within - 53 to -33 region from element $\mathrm{V}$ of the Apo B promoter (Kardassis et al., 1992). In this study, we have examined murine melanoma cells (B16/ $\mathrm{F} 10$ ), whether $\mathrm{C} / \mathrm{EBP}$ a bound to -53 to -33 may also interact synergically with HNF-4 and C/EBP a proteins localized in the -86 to -33 region of the $A$ poB promoter and to stimulate transcription of the apoB gene.

\section{MATERIAL AND METHODS}

\section{Material}

B16-F10 murine melanoma cells were purchased from American Type Culture Collection (Manassas, VA), while $\left[\mathrm{g}^{32} \mathrm{P}\right]$ ATP $(5000 \mathrm{Ci} / \mathrm{mmol})$ and $\left[{ }^{3} \mathrm{H}\right]$ chloramphenicol $(30 \mathrm{Ci} / \mathrm{mmol})$ were purchased from Amersham (Amersham Pharmacia Biotech Inc., Piscataway, NJ, USA). Transformation competent bacterial HB101 cells, polynucleotide kinase, ONitrophenyl- $\beta$-D-galactopyranoside, RSV- $\beta$-galactosidase plasmids and double-stranded poly $(\mathrm{dI}-\mathrm{dC})$ were all acquired from Invitrogen (Life Technology Inc.,Rockville, MD, USA).

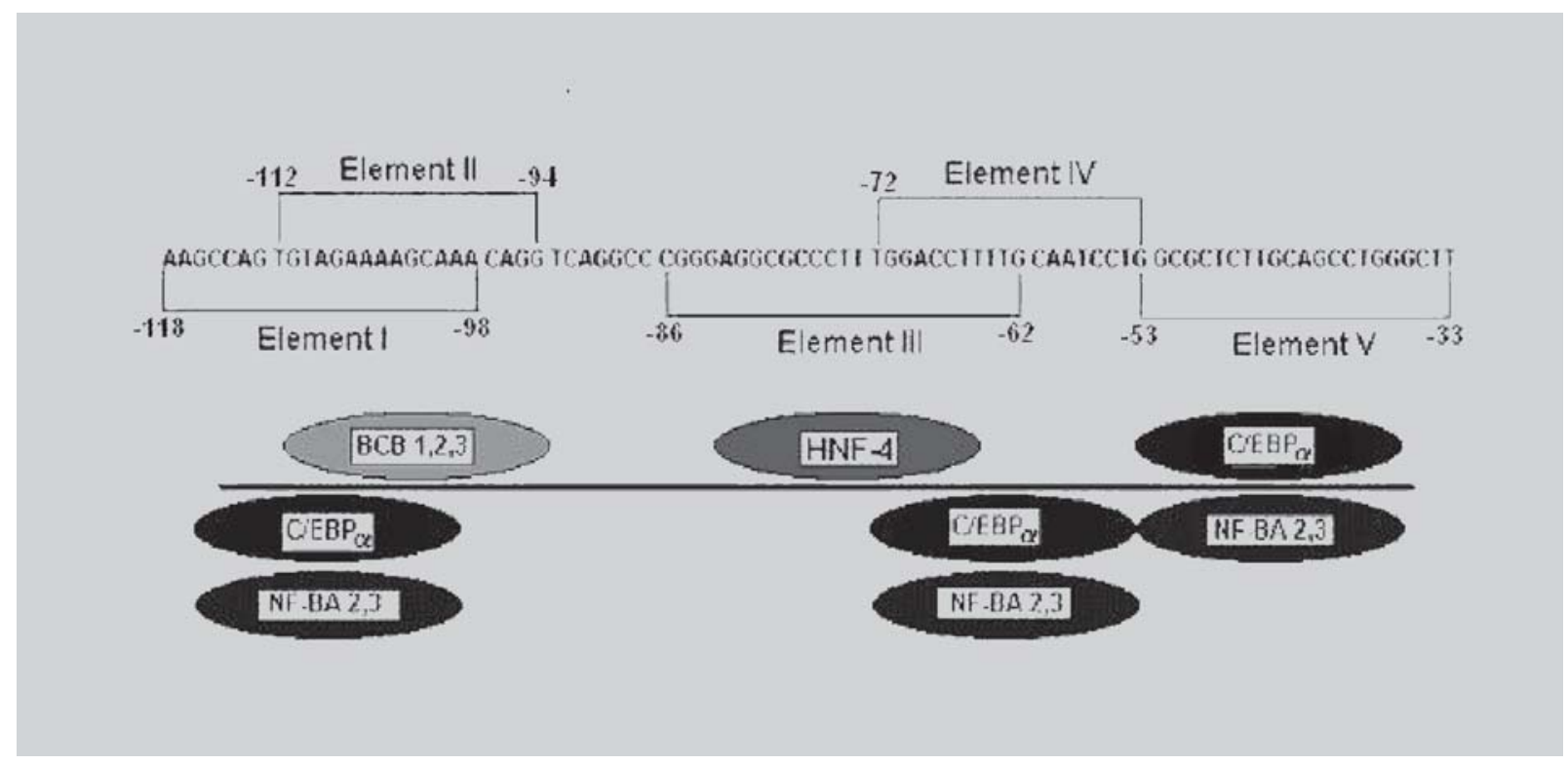

FIGURE 1 - Schematic representation of transcription factors binding to regulatory region $\mathrm{I}$ to $\mathrm{V}$ on the promoter region -118 to -33 of the human ApoB gene. The five regulatory elements and the binding activities that interact with them are shown as described by Kardassis et al. (1992). The circles represent transcription factors BCB 1, 2, 3; HNF-4 (NF- BA1); C/EBPa and HNF-4 (NF-BA 2, 3). 


\section{Methods}

\section{Nuclear extract preparation and protein purification}

Male Sprague-Dawley rats (200-250g) were housed in a climate controlled $\left(21^{\circ} \mathrm{C}\right)$ room with a 12 hour light-dark cycle and were given tap water. The Animal Ethics Committee of the University of Sao Paulo Medical School approved all experimental protocols. Rat liver nuclear extracts were prepared as previously described (Kardassis et al., 1990; Ogami et al., 1990; Kardassis et al., 1992). Two hundred mg of crude rat liver nuclear extracts in NDB buffer $(25 \mathrm{mM}$ Hepes, $\mathrm{pH}$ 7, $40 \mathrm{mM} \mathrm{KCl}, 0.1 \mathrm{mM}$ EDTA, $10 \%$ glycerol, $5 \mathrm{mM}$ $\mathrm{MgCl}_{2}, 1 \mathrm{mM}$ dithiotreitol were heated at $85^{\circ} \mathrm{C}$ for 5 minutes. The extracts were placed on ice for $5 \mathrm{~min}$ and centrifuged for $5 \mathrm{~min}$ at $4{ }^{\circ} \mathrm{C}$. The supernatants were transferred and protein concentrations were determined spectrophotometrically using Bradford assay (Bradford, 1976). HNF-4 protein was purified from rat liver nuclear extract as described by Sladek et al., (1990). C/EBP $\alpha$ was purified from rat liver nuclear extract as described by Metzger et al., (1993). Crude rat liver nuclear extract was passed over a heparin - agarose column followed by a double-stranded DNA-cellulose column (Amersham Pharmacia Biotech Inc., Piscataway, NJ, USA). Both columns were washed with $2 \mathrm{ml}$ salt gradients $(0.1-1 \mathrm{M}$ $\mathrm{KCl})$. The fractions were assayed for activity by a gel retardation assay as described by Metzger et al., (1993), using double-stranded synthetic oligonucleotides $\mathrm{C} / \mathrm{EBP} \alpha$ with a sequence corresponding to -86 to -33 of the human apoB promoter (Figure 2). The active fractions from the DNA-cellulose column were then mixed, diluted to reduce salt. Next, they were heated for $6 \mathrm{~min}$ at $85^{\circ} \mathrm{C}$ in a boiling water bath. The sample was cooled on ice immediately and then centrifuged at $9,500 \mathrm{rpm}$ for $15 \mathrm{~min}$ to precipitate the insoluble material (Mertzger et al., 1993). After centrifugation, the heat-soluble material was passed over an affinity column made with the $\mathrm{C} / \mathrm{EBP} \alpha$ oligo, as described by Kadonaga and Tijan (1986).The C/EBP $\alpha$ site specific DNA binding activity was eluted in $0.8 \mathrm{M} \mathrm{NaCl}$. This $\mathrm{C} / \mathrm{EBP} \alpha$ and HNF-4 transcription factors were used in the eletrophoretic mobility shift assays (EMSA).

\section{Gel eletrophoretic mobility shift assays}

Synthetic double stranded oligonucleotides containing wild type -86 to -33 region apoB region (WT) and mutations that abolished binding of the $\mathrm{C} / \mathrm{EBP} \alpha$ to -53 to -33 region (M4), $\mathrm{C} / \mathrm{EBP} \alpha-72$ to -53 region (M3), mutation M3 with a thymidine inserted at -71 position (M5) and mutation $\mathrm{M} 4$ with a thymidine inserted at -71 position (M6) were used in EMSA (Figure 2). EMSA were performed using $2 \mu \mathrm{l} \mathrm{C/EBP} \alpha$ and/or $2 \mu 1 \mathrm{HNF}-4$ of purified nuclear protein prepared as above. DNA binding reactions were in $20 \mu \mathrm{l}$ reaction volume containing $25 \mathrm{nM}$ Hepes pH 7.6, 8\% Ficoll 400, $40 \mathrm{mM} \mathrm{KCl}, 1 \mathrm{mM}$ dithiothreitol, $5 \mathrm{mM} \mathrm{MgCl}, 3 \mu \mathrm{g}$ of poly (dI-dC). Following a $15 \mathrm{~min}$ incubation on ice, $3 \mathrm{fmol} \mathrm{g} \mathrm{P}{ }^{32}$ [ATP $(30,000 \mathrm{cpm})$ of labeled double stranded oligonucleotides WT, M3, M4, M5 and M6 were added, followed by incubation for $30 \mathrm{~min}$ on ice. The reaction mixture was then loaded directly onto a $4 \%$ polyacrylamide gel 1 X TAE (6.7 mM Tris, $3.3 \mathrm{mM}$ sodium acetate, 1 mM EDTA, pH 7.9) and electrophoreses at 10 Volts $/ \mathrm{cm}$ for $2-3 \mathrm{~h}$ at $4{ }^{\circ} \mathrm{C}$ with recirculization of the buffer (miniVE Vertical Electrophoresis system, Amersham Pharmacia Biotech Inc., Piscataway, NJ, USA). After the run, the gel was then dried and analyzed by autoradiography. For quantification, autoradiograms were scanned in a densitometer (LKB UltroScan XI Laser Densitometer, Amersham Pharmacia Biotech Inc., Piscataway,NJ, USA).

\section{Plasmid constructions}

To create the chloramphenicol acetyltransferase (CAT) constructions, double - stranded synthetic oligonucleotide containing promoter fragments with sequence to bind the -86 to -33 (WT), -86 to -53 (72BCAT) and -53 to -33 (33BCAT) of the ApoB promoter plus GATC at the 5 ' ends were generated by the polymerase chain reaction (PCR) amplification and fused to the CAT gene plasmids (pUSHCAT) as described by Kardassis et al. (1992). To CAT construct 86/33 BCAT, two ApoB promoter fragments extending from - 86 to -72 and -53 to -33 were obtained by PCR amplification and further ligated. Double-stranded oligonucleotide was cloned into SmaI and Asp -718 sites of the pUCSH-CAT vector as described previously (Ogami et al. 1990). Transactivation assay in murine melanoma cells (B16/ F10) was performed with pMT2 expression vector containing the HNF-4 cDNA as described by Sladek et al., (1990) and pMT2 expression vector containing the $\mathrm{C} / \mathrm{EBP} \alpha$ cDNA as described by Metzger et al. (1993).

\section{Cell cotransfection and chloramphenicol acetyltransferase assays}

Murine melanoma cells (B16-F10) were maintained in RPMI 1640 medium enriched with $10 \%$ heat-inactived fetal bovine serum (FBS), $100 \mathrm{U} / \mathrm{mL}$ penicillin, $10 \mu \mathrm{g} / \mathrm{mL}$ 
streptomycin, and $2 \mathrm{mM}$ L-glutamine for DNA transfection experiments. Cells were placed in $60 \mathrm{~mm}$ culture dishes at approximately 60 confluences and cultured for $18 \mathrm{~h}$ prior to transfection. Transfection experiments were performed with $5 \mu \mathrm{g}$ of the constructs: WT, or $72 \mathrm{BCAT}$, or $86 / 33 \mathrm{BCAT}$, or $33 \mathrm{BCAT}$ and cotransfected with $5 \mu \mathrm{g}$ of pMT2-HNF-4, $5 \mu \mathrm{g}$ of pMT2$\mathrm{C} / \mathrm{EBP} \alpha$, and $3 \mu \mathrm{g}$ of RSV- $\beta$-galactosidase plasmids. Cells were harvested $42 \mathrm{~h}$ post-transfection and lysed by freeze-thawing. Plasmid constructs were transfected into cells by the calcium phosphate DNA co-precipitation method (Graham and Van de Ebb, 1973). The $\beta$-glycosidase activity of the cell lysates was determined by spectrophotometrically by monitoring the hydrolysis of the synthetic substrate O-nitrophenyl galactoside, at a wavelength of $410 \mathrm{~nm}$ using a microplate reader (Diagnostic Pasteur-LP 400, BioRad, Lexington, USA), as described by Miller et al. (1976). The protein concentrations were determined using the Bradford assay (Bradford, 1976). The CAT activity of the cell lysate was determined in triplicate, as described by Neumann et al. (1987). The b-galactosidase activity of the cell extracts was used to normalize the efficiency of transfection (Gorman et al. 1982).

\section{RESULTS AND DISCUSSION}

As seen in Figure 3, the direct binding of the $\mathrm{C} / \mathrm{EBP} \alpha$ with oligonucleotides which contains wild type (- 86 to -33 ) region interacts with both region -53 to-33 (M4) (Figure 3, lane 1, Panel A), as with -72 to 53 region (M3) (Figure 3, lane 2, Panel A). Kardassis et al. (1992) suggested that $\mathrm{C} / \mathrm{EBP} \alpha$ protein bind to different affinities within these regions. Our results have confirmed this observation. In our case, we observed that $\mathrm{C} / \mathrm{EBP} \alpha$ protein alone binds more strongly to the $\mathrm{M} 3$ region than to the M4 region (Figure 3, lane 1 and 2, Panel A). HNF-4 protein also recognized the wild type region with a higher affinity (Figure 3, lane 3, Panel A). In addition, C/EBP $\alpha$ bound to element $\mathrm{V}$ and IV formed a protein-DNA complex that migrated slower than the HNF-4 and $\mathrm{C} / \mathrm{EBP} \alpha$ protein alone (Figure 3, lane 4 and 6, Panel A).

Our results using mutations in element $\mathrm{V}$ showed that $\mathrm{C} / \mathrm{EBP} \alpha$ bound to element $\mathrm{V}$ (Figure 3, lane 6, Panel A) formed ternary complex with $\mathrm{HNF}-4$ protein. These results are similar to observed with $\mathrm{C} / \mathrm{EBP} \alpha$ bound to element IV (Figure 3, lane 4, Panel A). We hypothesized that despite $\mathrm{C} / \mathrm{EBP} \alpha$ bound to element $\mathrm{V}$ produces a weak interaction with $\mathrm{HNF}-4$, this heat-stable factor also may be forming a complex with $\mathrm{HNF}-4$ and $\mathrm{C} / \mathrm{EBP} \alpha$ factors

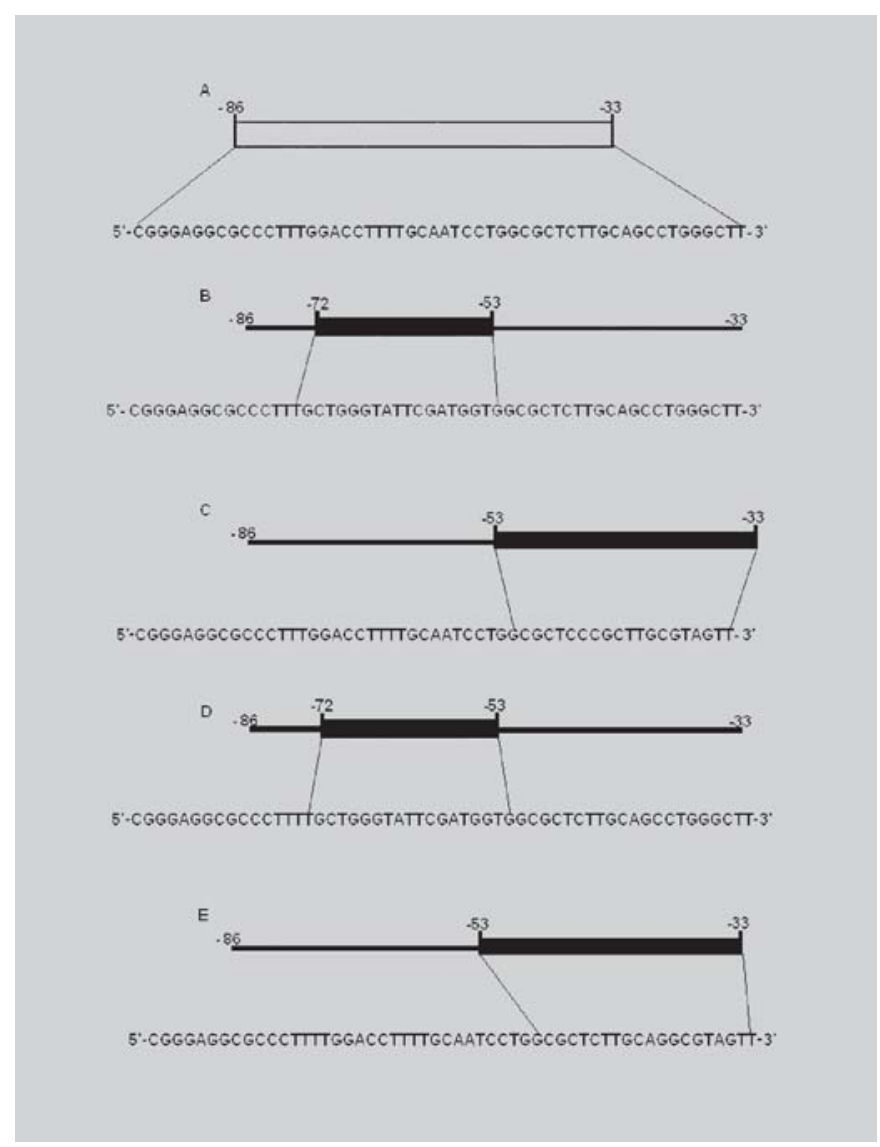

FIGURE 2 - Schematic representation of the oligonucleotide sequence of the promoter region of the ApoB gene used in EMSA. (A) Oligonucleotide sequence in the promoter region (-86 to -33) (WT). (B) Oligonucleotide sequence with mutation in element IV (-72 to -53) (M3). (C) Oligonucleotide sequence with mutation in element $\mathrm{V}$ (- 53 to -33), (M4). (D) Oligonucleotide sequence with mutation $\mathrm{M} 3$ and insertion of a thymidine nucleotide at the -71 position of the apoB promoter (M5). (E) Oligonucleotide sequence with mutation M4 and insertion of a thymidine nucleotide at the -71 position of the apoB promoter (M6). Mutations on the region of the ApoB promoters are shown by dark boxes.

bound to element III and IV, as reported by Kardassis et al. (1992) and Metzger et al. (1993). HNF-4 factor binds to regulatory region -86 to -62 , inducing a DNA helix bend, facilitating communication with $\mathrm{C} / \mathrm{EBP} \alpha$ proteins bound to element IV and located one helix turn from this HNF4 (Novak et al. 1998).

To define a probable physical interaction of the complex HNF4 factor bound -86 to -53 with $\mathrm{C} / \mathrm{EBP} \alpha$ proteins bound to -53 to -33 apoB region, we abolished by mutation At -71 position of apoB promoter, the interaction between HNF-4 and C/EBP $\alpha$ proteins bound to element $\mathrm{V}$ ( Figure 3, lane 5 and 7). 
A

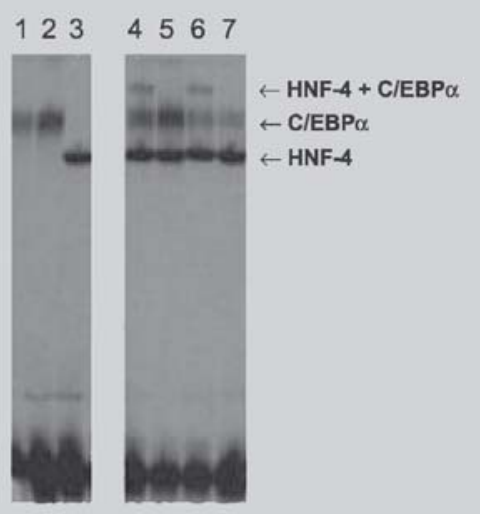

B 12

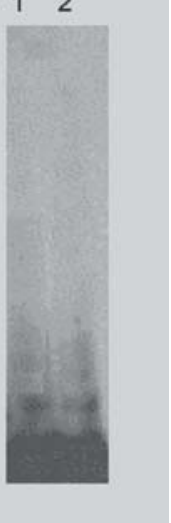

FIGURE 3 - Gel electrophoretic mobility shift analysis. (A) The transcription factors HNF-4 and $\mathrm{C} / \mathrm{EBP} \alpha$ from liver nuclear extracts incubated with radiolabelled double-stranded oligonucleotides WT, M3, M4, M5 and M6 were performed as described in material and methods. Lane 1- $2 \mu \mathrm{g}$ of C/EBP $\alpha$ protein incubated with $\mathrm{M} 4$. Lane 2- $2 \mu \mathrm{g}$ of $\mathrm{C} / \mathrm{EBP} \alpha$ protein incubated M3. Lane 3- $2 \mu \mathrm{g}$ of HNF-4 protein incubated with WT. Lane 4- $2 \mu \mathrm{g}$ of HNF-4 and $2 \mu \mathrm{g}$ of C/EBP $\alpha$ protein incubated with M3. Lane 5- $2 \mu \mathrm{g}$ of HNF-4 and $2 \mu \mathrm{g}$ of $\mathrm{C} / \mathrm{EBP} \alpha$ protein incubated with M5. Lane 6- $2 \mu \mathrm{g}$ of HNF-4 and $2 \mu \mathrm{g}$ of $\mathrm{C} / \mathrm{EBP} \alpha$ proteins binding to M4. Lane 7- $2 \mu \mathrm{g}$ of $\mathrm{HNF}-4$ and $2 \mu \mathrm{g}$ of $\mathrm{C} / \mathrm{EBP} \alpha$ proteins binding to M6; (B) The transcription factors $\mathrm{HNF}-4$ and $\mathrm{C} / \mathrm{EBP} \alpha$ from melanoma cells B16/F10 extracts were incubated with WT and M4 as described in materials and methods. Lane $1-2 \mu \mathrm{g}$ of $\mathrm{C} / \mathrm{EBP} \alpha$ protein incubated with probe M3. Lane 2- $2 \mu \mathrm{g}$ of HNF-4 protein incubated with probe WT. The arrow shows the low mobility band derived from HNF-4 and C/EBP $\alpha$ specific complexes. High mobility bands correspond to unbound probes.

Our findings showed that, under these conditions, the interactions between HNF-4 and both $\mathrm{C} / \mathrm{EBP} \alpha$ proteins bound to element IV or V were affected (Figure 3 , lane 5 and 7 , respectively). These results suggest that flexibility of the HNF-4 proteins is important factors to facilitate the interaction with $\mathrm{C} / \mathrm{EBP} \alpha$ factor bound to element $\mathrm{V}$. Probably, $\mathrm{C} / \mathrm{EBP} \alpha$ proteins bound to -53 to -33 region may be acting synergistically with complex formed between HNF-4 protein and C/EBP $\alpha$ proteins localized in -86 to -53 region of the apoB promoter. Murine melanoma cell were used due to the lack of expression of apoB or HNF-4 or $\mathrm{C} / \mathrm{EBP} \alpha$ transcription factor (Figure 3, lane 1 and 2, Panel B).

To further examine the effect of activity of the $\mathrm{C} / \mathrm{EBP} \alpha$ protein bound to the element $\mathrm{V}$ on apoB transcription, we studied the activation of CAT reporter constructs by $\mathrm{C} / \mathrm{EBP} \alpha$ in murine melanoma cells, B16/F10 (Figure 4). These findings

have shown that transient transfections in B16/F10 cells with plasmid -33BCAT reduced transcription of $2 \%$ control (wt), while the transfections with plasmid -86/-33BCAT reduced the transcription of the apoB gene to $10 \%$. These results showed that the binding of $\mathrm{C} / \mathrm{EBP} \alpha$ in the -53 to -33 regions is also important for the transcription of the apoB gene. Moreover, transients transfection by plasmid -86/-53BCAT in melanoma cells (B16/F10) reduced to $6 \%$ of the wild type. Similar results were found for HepG2, where mutations that prevent bonds of HNF-4 in the -86 to -62 region and C/EBP $\alpha$ in the -72 to -53 region to their cognate sites have reduced the promoter activity to 2-13\% of control (wt) (Kardassis et al., 1992). Transcription from the apoB promoter is strongly dependent on the specific binding of $\mathrm{C} / \mathrm{EBP} \alpha$ proteins to element IV and $\mathrm{V}$ and their interaction with HNF-4. Finally, these findings suggest that $\mathrm{C} / \mathrm{EBP} \alpha$ bound in the -53 to -33 regions may contribute to a higher level of expression of the ApoB gene. Thus, CAT transfection can only provide suggestive evidence of the physiological role of the $\mathrm{C} / \mathrm{EBP} \alpha$ in the -53 to -33 regions. However, the precise role of this transcription factor in apoB expression still remains unclear. In this reporter, we do argue that $\mathrm{C} / \mathrm{EBP} \alpha$ bound -53 to -33 region could be physically interacting with HNF-4 and C/EBP $\alpha$ (-86 to -53 ) affecting apoB gene transcription.

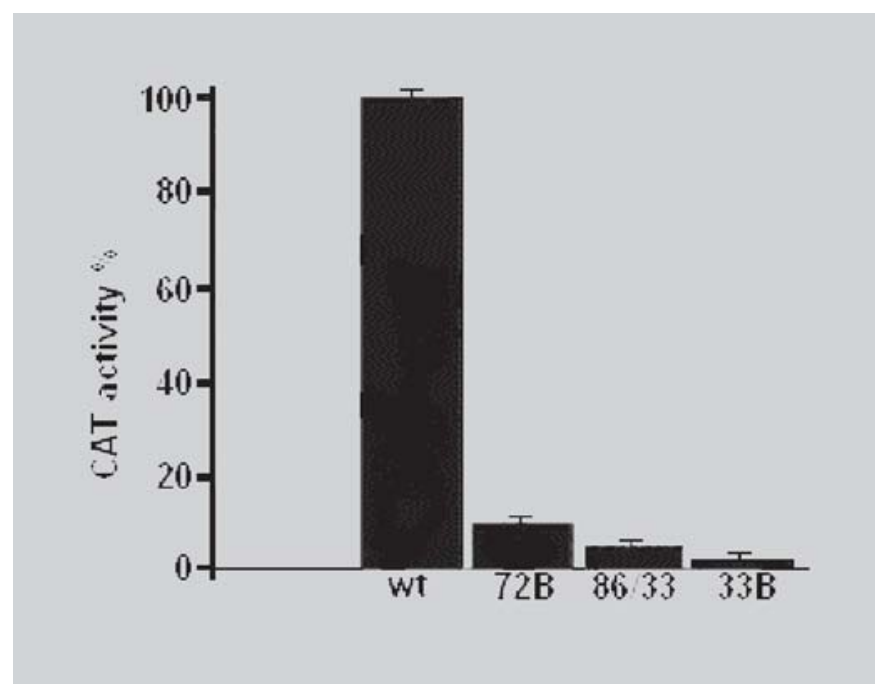

FIGURE 4 - Transactivation of the region of apoB promoter. CAT assays were analyzed as described in materials and methods. B16/F10 cells were transfected with $5 \mathrm{mg}$ of the four constructs: WT, 72BCAT, 86/33BCAT, 33BCAT, and co-transfected with $5 \mu \mathrm{g}$ of pMT2HNF-4 and pMT2-C/EBP $\alpha$ plasmids, and $3 \mu \mathrm{g}$ of RSV-b galactosidase plasmid. The normalized relative CAT activities (mean \pm SEM) of at least three independent experiments performed in duplicate are shown in the form of a bar graph. 


\section{RESUMO}

\section{Estudo da atividade do fator de transcrição C/EBP $\alpha$ na região $-\mathbf{5 3}$ a $-\mathbf{3 3}$ do promoter do gene da apolipoproteina $\mathrm{B}$}

A apolipoproteina B (apoB) tem um importante papel na regulação na homeostasia celular, do colesterol e na patogênese da aterosclerose. Esta proteína age como ligante para o reconhecimento e catabolismo lipoproteinas de baixa densidade (LBD) através do receptor de LDL. Estudos anteriores mostraram que a expressão do gene da apolipoproteína $B(A P O B)$ em células hepáticas é regulada pela interação de fatores ligados ao elemento enhancer no intron 2, e em 3 elementos denominados de III, IV e V localizados nas regiões -86 a $-62,-72$ a -53 e -53 a -33, respectivamente, do promotor do gene da $A P O B$. Neste trabalho, nós sugerimos que o fator de transcrição $C / E B P \alpha$ ligado a região -53 a -33 da APOB interage com o complexo $H N F-4$ e C/EBP $\alpha$ localizado dentro da região -86 a -53 do APO B e contribui para aumentar a transcrição do gene $A P O B$.

UNITERMOS: Apolipoproteina B. Fator de transcrição C/EBPa. Fator de transcrição HNF-4. Células de melanoma-B16/F10.

\section{REFERENCES}

BARTER, P. J.; BALLANTYNE, C. M.; CARMENA, R.; CASTRO CABEZAS, M., Apo B versus cholesterol in estimating cardiovascular risk and in guiding therapy: report of the thirty-person/ten-country panel. J. Intern. Med., v.259, p.247-258, 2006.

BRADFORD, M. M. A rapid and sensitive method for the quantification of microgram quantities of protein utilizing the principle of protein-dye binding. Anal Biochem., v.72, p.248-254, 1976.

BRESLOW, J. L. Human apolipoprotein genetic variation. Physiol. Rev., v. 68, p. 85-132, 1988.

BROOK, A. R.; Levy-Wilson, B. Hepatocyte nuclear factor 1 and C/EBP are essential for the activity of the human apolipoprotein B gene second intron enhancer. Mol. Cell. Biol., v.12, p.1134-1148, 1992.

BROWN, M.S.; GOLDSTEIN, J.L. receptor - mediated pathway for cholesterol homeostasis. Science, v. 232, p. 34-47, 1986.
GOLDSTEIN, J.L.; Brown, M.S. Atherosclerosis: the lowdensity lipoprotein receptor hypothesis. Metabolism, v. 26, p. 1257-75, 1977.

GOLDSTEIN, J.L.; KITO, T.; BROWN, M.S. Defective lipoprotein receptors and atherosclerosis. New Engl. J. Med., v. 309, p. 288-296, 1983.

GORMAN, C.M.; MOFFAT, L.F.; HOWARD, B.H. Recombinant genomes which express chloramphenicol acetyltransferase in mammalian cells. Mol. Cell Biol., v.2, p.1044-1051, 1982.

GRAHAM,F.L.; VAN der EB. A new technique for the assay of infectivity of human adenovirus 5 DNA. Virology, v. 52, p. $456,1973$.

GRUNDY, S.M. Metabolic syndrome: therapeutic considerations. Hand. Exp. Pharmacol., v. 170, p. 107133. 2005.

HUANG, C.; MASON, J.T. Structure and properties of mixed - chain phospholipids assemblies. Biochim. Biophys. Acta, v. 864, p. 423-70, 1986.

KADONAGA, J.T.; TJIAN, R. Affinity purification of sequence-specific DNA binding proteins. Nucleic Acids Res., v. 15, p. 8125-8143, 1986.

KARDASSIS, D.; HADZOPOULOU-CLARADAS, M.; RAMJI, D.P.; CORTESE, R.; ZANNIS, V.I.; CLARADAS, C. Characterization of the promoter elements required for hepatic and intestinal transcription of the human apoB: gene definition of the DNA-Binding site of a tissue specific transcriptional factor. Mol. Cell. Biol., v.10, p. 2653-2659, 1990.

KARDASSIS, D.; ZANNIS, V.I.; CLARADAS C. Organization of the regulatory Elements and Nuclear Activities Participating in the Transcription of the Human Apolipoprotein B Gene. J. Biol. Chem., v. 267, p.2622-2632, 1992.

LANDSCHULTZ, W. H.; JOHNSON, P. F.; McKnight, S. I. The leucine zipper: A hypothetical structure common to a new cass of DNA binding proteins. Science, v. 240, p. 1759-1764, 1988.

LILJA, H.; KAMOHARA, Y.; NEUMANN, T.; DEMETRIOU, A.A.; ROZGA, J. Transformation growth factor $\mathrm{b} 1$ helps maintain differentiated functions in mitogen-treated primary rat hepatocyte cultures. Mol.Cell.Biol.Res. Commum.,v. 1, p. 188-195, 1999. 
MERTZGER, S.; HALA, J.; BRESLOW, J. L.; SLADEK, F. M. Orphan receptor HNF-4 and bZip protein C/EBP $\alpha$ bind to overlapping regions of the apolipoprotein $\mathrm{B}$ gene promoter and synergically active transcription. J. Biol. Chem., v.268, p. 16831-1638, 1993.

MILLER, J. H. Experiments in molecular genetics. J. Biol. Chem., v. 251, p. 3774-3779,1976.

NEUMANN, J. R.; MORENCY, A.C.; RUSSIAN, K.O. A novel rapid assay for chloramphenicol acetyltransferase gene expression. Biotechniques, v. 5, p.444,1987.

NOVAK, E.M.; DANTAS, K.C.; CHARBEL, C. E.; BYDLOSWKI, S. P. Association of hepatic nuclear factor-4 in the Apolipoprotein B promoter: a preliminary report. Braz. J. Med. Biol. Res., v. 31, p. 140-3, 1998.

OGAMI, K.; HADZOPOULOU-CLARADAS, M.; CLARADAS, C.; ZANNIS, V. I. Promoter elements and factors require for hepatic and intestinal transcription of the human Apo CIII gene. J. Biol. Chem., v. 265, p. 99089815, 1990.

OLOFSSON S, BORÉN J. Apolipoprotein B: a clinically important apolipoprotein which assembles atherogenic lipoproteins and promotes the development of atherosclerosis. J. Intern. Med., v. 258, p.359-410, 2005.
SATTAR, N.; WILLIAMS, K.; SNIDERMAN,A.L.; D'ÁGOSTINO, R.; HAFFNER, S. Comparison of the associations of apolipoprotein B and Non-High-density lipoprotein cholesterol with other cardiovascular risk factor in patients with the metabolic syndrome in the insulin resistance atherosclerosis study. Circulation, v.110, p.2687-2693, 2004.

SLADEK, F. M.; ZHONG, W.; LAI, E.; DARNELL, Jr. J. E. Liver, enriched transcription factor HNF-4 is a novel member of the steroid hormone receptor super family. Genes Dev., v. 4, p. 2353-2365, 1990.

THOMPSON A.; DANESH J. Associations between apolipoprotein B, apolipoprotein AI, the apolipoprotein $\mathrm{B} / \mathrm{AI}$ ratio and coronary heart disease: a literature-based meta-analysis of prospective studies. J. Intern. Med., v.259, p.481-492, 2006.

ZANNIS, V. I.; KAN, H. Y.; KRITIS, A. Transcriptional regulation of the human Apolipoprotein genes in vitro and in vivo. Curr. Opin. Lipidol., v.12, p. 181-207, 2001.

Recebido para publicação em 21 de março de 2005. Aceito para publicação em 07 de junho de 2006. 